\title{
Characterization of Nitrate Contamination in an Arid Region of China
}

\author{
Guangwei Huang \\ Graduate School of Global Environmental Studies, Sophia University, Tokyo, Japan. \\ Email: huang@genv.sophia.ac.jp
}

Received May $28^{\text {th }}, 2013$; revised June $28^{\text {th }}, 2013$; accepted July $9^{\text {th }}, 2013$

Copyright (C) 2013 Guangwei Huang. This is an open access article distributed under the Creative Commons Attribution License, which permits unrestricted use, distribution, and reproduction in any medium, provided the original work is properly cited.

\begin{abstract}
There are two pathways for nitrate to enter into human body: drinking water and food. Therefore, nitrate contamination of drinking water and agricultural crops is of particular interest to governments and the general public owing to the possible implications for health. This work investigated nitrate contents in various crops and in different parts of each crop and in drinking water as well in the Zhangye Basin, Northwest China. It provided evidence of severe nitrate contamination of drinking water, especially, in vegetable-growing villages. As to the nitrate contamination of crops, the present study revealed that all sampled crops adjust their nitrate distributions in a way that the edible parts contain much less nitrate than non-edible parts except lettuce. The nitrate content in the edible root of lettuce reached up to $5900 \mathrm{mg} / \mathrm{kg}$ exceeding the limit set by the European Commission.
\end{abstract}

Keywords: Nitrate Contamination; Drinking Water; Crops; Zhangye Basin

\section{Introduction}

This Nitrate $\left(\mathrm{NO}_{3}^{-}\right)$is an integral part of the nitrogen cycle in the environment. It is oxidized form of nitrogen and highly soluble in water. It is invisible, odorless and tasteless. Nitrate is commonly found in soil and water and is the most effective form by which plants obtain their nitrogen. However, it is also most readily lost from soil by leaching in drainage water, which may be considered as one of the reasons for over-application of nitrogen fertilizers $[1,2]$.

To meet the food demand of the growing world population, continued increases in food production is a necessity. Since the mid-19th century, nitrogen has been used in the agricultural system to boost productivity. It was reported that the nitrogen use increased four-fold in USA between 1960 and 1989 [3]. During the same period, the nitrogen use in China increased 15 times according to China Year Book. Presently, China has become the largest consumer of synthetic nitrogen in the world, accounting for $32 \%$ of the world's total nitrogen consumption [4].

A particular concern of nitrogen use in agricultural practices is the nitrate contamination in waters and accumulation in agricultural products. The primary reason for the concern is the threat it poses to human health. The toxicity of nitrate to humans is mainly attributable to its reduction to nitrite. The major biological effect of nitrite in humans is its involvement in the oxidation of normal Hemoglobin $(\mathrm{Hb})$ to met-Hemoglobin (met-Hb), which is unable to transport oxygen to the tissues. The $\mathrm{Hb}$ of young infants is more susceptible to met-Hb formation than that of older children and adults. Drinking water with elevated nitrate levels has been highlighted as the cause of the so-called "blue baby syndrome" [5]. It is also associated with respiratory and reproductive system illness, some cancers, and thyroid problems [6,7]. Study by Parslowa et al. [8] indicated a positive relationship between the incidence of childhood-onset insulin-dependent diabetes mellitus and levels of nitrate in drinking water. On the other hand, studies have shown that vegetables eaten by people contribute about $72 \%-94 \%$ of the total daily intake of nitrate $[9,10]$. De Martin and Restani [11] showed that leafy green vegetables accumulate high amounts of nitrate, concentrations reaching up to 6000 $\mathrm{mg} / \mathrm{kg}$. Through a 7-year survey in Slovenia, Susin et al. [12] reported that the average nitrate contents of their samples were the highest in lettuce $(1074 \mathrm{mg} / \mathrm{kg})$, cabbage $(881 \mathrm{mg} / \mathrm{kg})$, string beans $(298 \mathrm{mg} / \mathrm{kg})$ and carrot $(264 \mathrm{mg} / \mathrm{kg})$, and they were moderately high in potato $(158 \mathrm{mg} / \mathrm{kg})$, silage maize $(122 \mathrm{mg} / \mathrm{kg})$, strawberries $(94$ $\mathrm{mg} / \mathrm{kg}$ ), cucumbers $(93 \mathrm{mg} / \mathrm{kg}$ ) and cereals $(49 \mathrm{mg} / \mathrm{kg})$. 
Besides, low nitrate contents (below $6 \mathrm{mg} / \mathrm{kg}$ ) were found in fruit (grapes, peaches, apples and pears) and tomato. Petersen and Stoltze [13] surveyed the contents of nitrate and nitrite in lettuce, leek, potato, beetroot, Chinese cabbage and white cabbage on the Danish market. The highest content of nitrate was found in lettuce followed by beetroot and Chinese cabbage. They further estimated human's daily intake of nitrate from the vegetables. Zhong et al. [14] investigated the contents of nitrate and nitrite in potato, cabbage, Chinese cabbage, scallion, celery, cucumber, tomato, eggplant and wax gourd taken in Northern China. The highest content of nitrate was found in celery followed by Chinese cabbage, cabbage, scallion, wax gourd and eggplant. The study by Ayaz et al. [15] indicated that nitrate concentrations in vegetables in Turkey are low and of little concern. The mean content of nitrate in vegetable-based infant foods of Estonian origin was reported to be $88 \mathrm{mg} / \mathrm{kg}$ and the average daily intake of nitrate by children in the age group of $4-6$ years was estimate to be $30 \mathrm{mg}$ [16].

The above-mentioned studies have greatly improved the understanding on the possible range of nitrate content in various agricultural products. However, they did not consider nitrate distribution in crops. Santamaria et al. [17] showed that the nitrate content in vegetable organs can be listed in the decreasing order from petiole, leaf, stem, root to seed. Andrews [18] proposed that a greater proportion of nitrate assimilation occurs in the shoot when an increase in the rate of nitrate uptake does not induce an increase in nitrate reductase level in the root. Overall, knowledge on nitrate distribution in agricultural crops is still relatively limited.

The present study focused on an arid region of China where groundwater contamination by nitrate due to intensive farming has been reported. Nitrate contents in various crops and drinking water in the region were measured. The objective is to report the current state of nitrate contamination of crops and drinking water in this region.

It should be noted that the Joint Expert Committee on Food Additives and the European Commission's Scientific Committee on Food have set an Acceptable Daily Intake (ADI) for nitrate of $3.7 \mathrm{mg} / \mathrm{kg}$ bodyweight, which is equivalent to $220 \mathrm{mg}$ per day for an adult of $60 \mathrm{~kg}$ [19, 20]. Therefore, it may be stated that infants are more vulnerable to nitrate contamination in drinking water while adults are more affected by nitrate accumulation in foods.

In the present study, the investigations on nitrate contamination were conducted mainly in the middle reaches of the Heihe River (or the Zhangye Basin) every summer from 2009 to 2012 .

\section{Materials and Methods}

The middle reaches of the Heihe River was chosen as our study area. Heihe River is the second largest inland river in China. Its main stream, with a length of $821 \mathrm{~km}$, originates from the Qilian Mountains of Qinghai Province, flows through the Zhangye Basin, which is part of the ancient Silk Road, and ends up in the Inner Mongolia Autonomous Region. The catchment of the middle reaches, or the Zhangye Basin, covers an area of $1.08 \times$ $10^{4} \mathrm{~km}^{2}$ extending from $38^{\circ} 30^{\prime}$ to $39^{\circ} 50^{\prime} \mathrm{N}$ and $99^{\circ} 10^{\prime}$ to $100^{\circ} 52^{\prime} \mathrm{E}$. Along the main stream, the middle reaches starts from the Yingluo Gorge and ends at the Zhengyi Gorge (Figure 1).

Zhangye Basin is characterized by a dry continental climate, with mean annual precipitation of about $200 \mathrm{~mm}$, and annual evaporation of $2000 \mathrm{~mm}$ or more. The renewable water resource per capita in Zhangye is 1250 $\mathrm{m}^{3} / \mathrm{yr}$, just $5 \%$ of the world average. Since 2001 , about $50 \% \sim 60 \%$ of the annual total river discharge have been diverted from the middle to the lower reaches of the river following the regulation imposed by the Ministry of Water Resources of China (MWR). Consequently, groundwater abstraction and sewage water reuse for agricultural purpose have been increasing gradually to compensate for the reduced river water supply.

Grain crops, particularly seed corn, are densely cultivated in the Zhangye Basin, sustained by the continuous application of chemical nitrogen fertilizers. In 2005, the total amount of nitrogen fertilizers applied on the corn fields was more than $300 \mathrm{~kg} \cdot \mathrm{ha}^{-1} \cdot$ year $^{-1}$ and, more recently, was more than $450 \mathrm{~kg} \cdot \mathrm{ha}^{-1} \cdot$ year $^{-1}$ [21].

The study by Yang and Liu [22] showed that 32.4\% of the groundwater well samples in Zhangye had nitratenitrogen concentrations greater than the allowed value set by the WHO. Fang and Ding [23] reported the nitrate



Figure 1. Watershed of the Heihe River. 
concentration of groundwater as high as $84.1 \mathrm{mg} / \mathrm{L}$ in the urbanized area of the Zhangye Basin and about $67 \%$ of irrigation land area was associated with medium (13 - 30 $\mathrm{mg} / \mathrm{L})$ nitrate concentration. Zhang et al. [24] reported nitrate concentrations in groundwater ranging from 45 to $150 \mathrm{mg} / \mathrm{L}$ in irrigated area. Field survey by Qin et al. [25] also showed that groundwater with high nitrate concentration $(>45 \mathrm{mg} / \mathrm{L})$ appeared in the centre of the irrigated area. However, these studies did not make distinction between wells for drinking and wells for irrigation or other purposes. Therefore, nitrate contamination of drinking water in the region could not be inferred from their findings.

It should be noted here that although the WHO limit for nitrate-nitrogen in drinking water is $10 \mathrm{mg} / \mathrm{L}$ or equivalent to $45 \mathrm{mg} / \mathrm{L}$ for nitrate, Chinese standard for nitrate-nitrogen in drinking water issued in 1986 is $20 \mathrm{mg} / \mathrm{L}$ or equivalent to $90 \mathrm{mg} / \mathrm{L}$ for nitrate.

For drinking water investigation, samples were directly taken from household by home visit. The drinking water resource in the Zhangye Basin is groundwater. The supply system is the construction of community drinking well and water tower to distribute potable water through pressurized pipe network to each household within a community. The number of household surveyed was 5 in 2009, 20 in 2010, 16 in 2011 and 8 in 2012. Except 2012, home visits were randomly conducted in various villages across the basin. In 2012, drinking water testing was conducted in villages where the nitrate concentrations in crops were measured.

In the Zhangye Basin, there are three sources of irrigation water: river water; groundwater and the mixture of river water and sewage water. The use of sewage water for irrigation is because of water scarcity. In this study, three types of farmland using different source of water for irrigation were selected (Figure 2). Gaozai and Genming villages are located in the northeast and north part of the Zhangye City, where the irrigation water is of the mixed type. Guojiabao and Erzha villages are relatively close to the urbanized area of the city, where the source of irrigation water is groundwater. Yangjiazha village is in the southern part of the city and uses river water for irrigation. Crop samples were taken from these fields and on-site measurements of nitrate concentration were conducted. The method is to extract out plant juice of a volume between $0.3 \mathrm{ml}$ and $2 \mathrm{ml}$ from crop sample, and measure its nitrate concentration with the Horiba compact nitrate ion meter (LAQUAtwin-B741), which is based on the colorimetric method of Gilbert [26]. The sensor was calibrated by the two-calibration mode with $300 \mathrm{mg} / \mathrm{kg}$ and $5000 \mathrm{mg} / \mathrm{kg}$ standard solutions on a daily base. For seed-corn plant, the measurements were conducted every $10 \mathrm{~cm}$ along the stalk from the brace roots to the top flag leaf. Moreover, the nitrate concentration of corn niblets

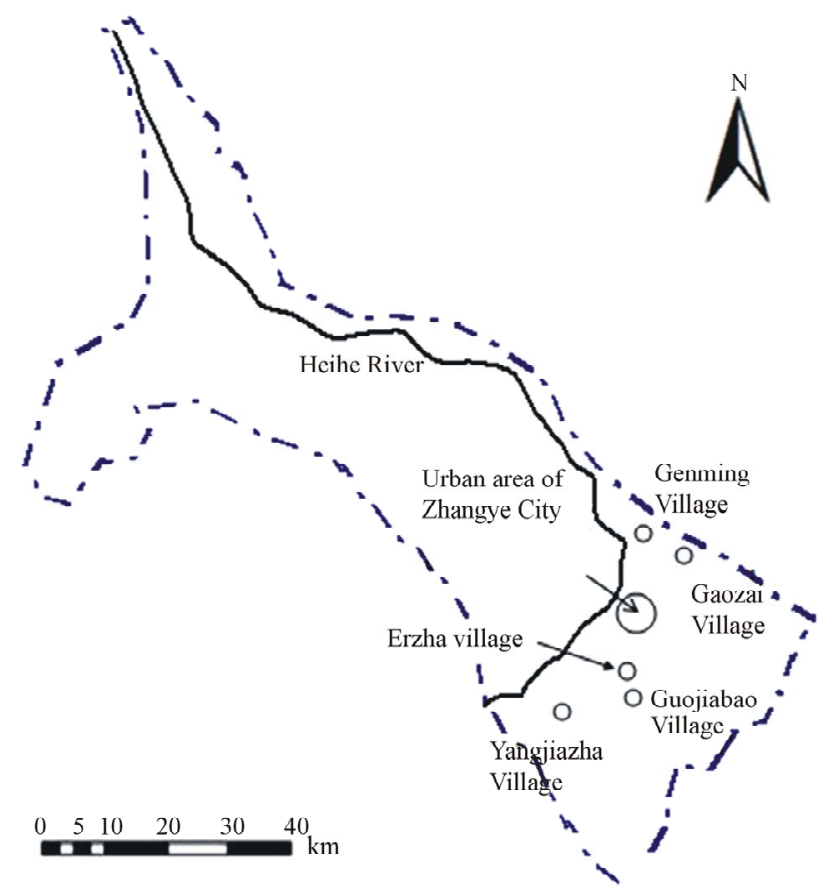

Figure 2. Zhangye Basin and sampling sites for the 2012 survey.

was also measured. For comparison, both mature and immature corn plants were measured. For vegetables, leaf and root were measured separately. In addition, the nitrate concentrations of irrigation water entering into the fields were measured with the Horiba compact nitrate ion meter (LAQUAtwin-B743) for water. The investigation on the build-up of nitrate in crops was conducted from August 8 to 18,2012 . All measurements were done under fine weather during daytime.

\section{Results and Discussion}

In 2009, two households out of five were found to drink water having nitrate concentrations above the WHO standard. The highest nitrate concentration found in the 2009 survey was $75 \mathrm{mg} / \mathrm{l}$. When asking if they are concerned about nitrate contamination, one of the householders answered that there is no worry because they boil water before drinking. This highlighted the need of basic science education for farmers in this region because boiling can't remove nitrate.

In 2010, drinking water testing found that eight households out of twenty having nitrate contents exceeding the WHO standard with the highest value of nitrate being 160 $\mathrm{mg} / \mathrm{l}$. In 2011, nine out of sixteen were above the WHO standard. The percentage of different levels of nitrate observed during the three years was shown in Figure 3. It can be seen that the potable water in $40 \%$ of the households surveyed contained nitrate contents more than the WHO allowed. 
In 2012, although the survey mainly focused on nitrate contamination of crops in four villages, nitrate in drinking water was also tested at the same time.

In the Gaozai village, we randomly selected two corn plants; one mature and another immature. The maturity is judged by the size and color of corn ears. The mature corn ear was $20 \mathrm{~cm}$ long and golden color while the immature was $10 \mathrm{~cm}$ long and pale green color. Figure 4(a) shows the nitrate concentration distributions along the two corn stalks. In the mature plant, the nitrate concentration was as high as $3700 \mathrm{mg} / \mathrm{kg}$ at the brace roots but

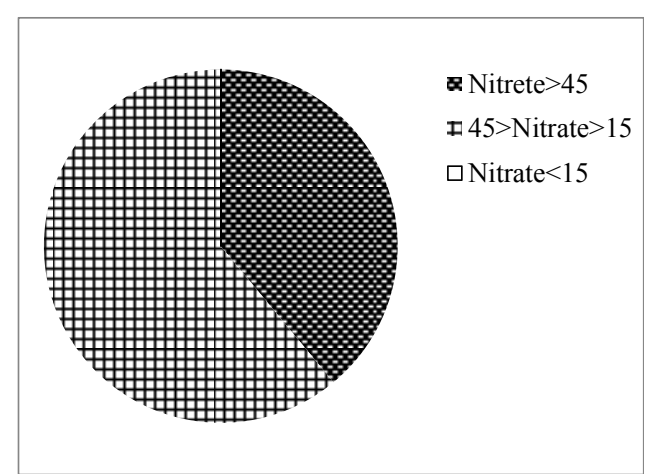

Figure 3. Percentage of different nitrate levels found in drinking water from 2009 to 2011.

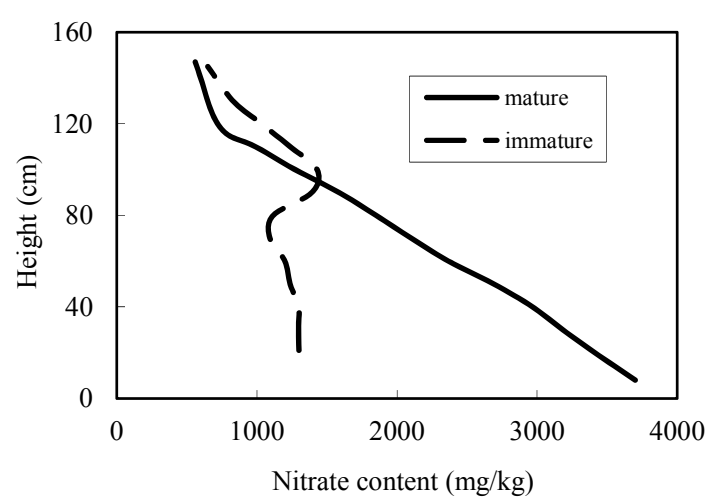

(a)

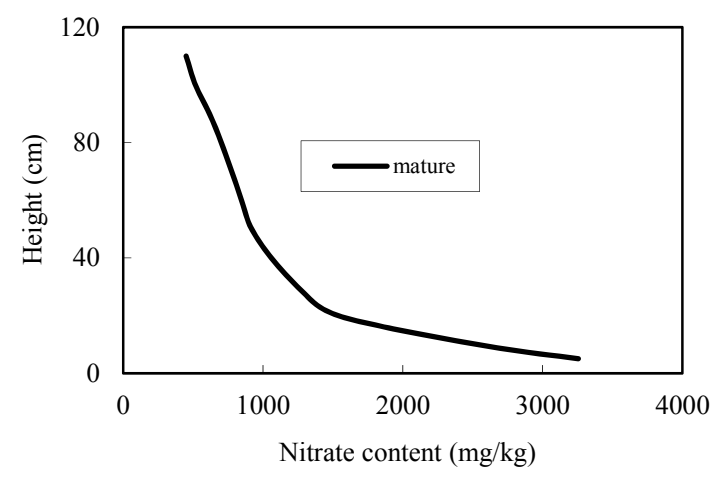

(b)

Figure 4. Nitrate distributions in corn stalks. (a) Sewageriver mixed water irrigation case; (b) River water irrigation case. decayed quickly along the stalk. In the immature plant, the nitrate concentration at the bottom was not significantly higher than the top. The maximum concentration occurred somehow in the middle of the plant where a single ear grew. The nitrate concentrations in niblets of both the mature and immature corns were $110 \mathrm{mg} / \mathrm{kg}$ and $210 \mathrm{mg} / \mathrm{kg}$, respectively. This comparison suggests that the corn plant adjust its nitrate build-up through its growing stage in a way that the edible part contains the least nitrate. In other words, the final distribution of nitrate in corn plant is in favor of human beings. For water entering into the farmland where corn samples were taken, the concentrations of nitrate and ammonium $\left(\mathrm{NH}_{4}^{+}\right)$ were found to be $20 \mathrm{mg} / \mathrm{kg}$ and $6 \mathrm{mg} / \mathrm{L}$, respectively. The ammonium concentration was measured with the DR/890 Portable Colorimeter manufactured by the $\mathrm{HACH}$ Company. The data implies that high ammonium coming from waste water was converted to nitrate and then utilized by plants.

In the Genming village, which is about $10 \mathrm{~km}$ downstream of the Gaozai village, the concentration of nitrate in the irrigation channel was found to be as high as 110 $\mathrm{mg} / \mathrm{kg}$ but $0.2 \mathrm{mg} / \mathrm{L}$ for ammonium. And the nitrate concentrations in corn plants taken from that village showed a very similar pattern as that observed in the Gaozai village. In this mixed water-irrigated area, mass production of vegetables is non-existent. According to interview with local farmers, vegetables could not be grown with the mixed water.

In the Yangjiazha village where the water from the Heihe River is used for irrigation, the nitrate concentration in the sampled corn plant is shown in Figure 4(b). The corn plant in this river-water-irrigated area shared similar characteristics with that in the mixed-water irrigated area in terms of the vertical decreasing pattern. However, the nitrate concentration in the river-water-fed plant decreased vertically much fast than the mixed-water-fed plant. Therefore, the total build-up of nitrate is much less if river water is used for irrigation. The nitrate concentration of the irrigation water in the village was measured to be $15 \mathrm{mg} / \mathrm{L}$. The indifference in the concentration of root part with regard to the source of irrigation water can be considered as indicative of excessive use of nitrogen fertilizer in the river-water-fed field.

In total, 10 mature seed corns were sampled in the Zhangye Basin during the August 2012. The concentrations of root part varied from $3300 \mathrm{mg} / \mathrm{kg}$ to $3700 \mathrm{mg} / \mathrm{kg}$ with the mean and standard deviation being $3588 \mathrm{mg} / \mathrm{kg}$ and $118 \mathrm{mg} / \mathrm{kg}$, respectively. Meanwhile, the concentrations of top part varied from $450 \mathrm{mg} / \mathrm{kg}$ to $770 \mathrm{mg} / \mathrm{kg}$ with the mean and standard deviation being $624 \mathrm{mg} / \mathrm{kg}$ and $132 \mathrm{mg} / \mathrm{kg}$, respectively. Moreover, the concentrations of corn niblets varied from $96 \mathrm{mg} / \mathrm{kg}$ to $210 \mathrm{mg} / \mathrm{kg}$ with the mean and standard deviation being $146 \mathrm{mg} / \mathrm{kg}$ 
and $41 \mathrm{mg} / \mathrm{kg}$, respectively.

In the Guojiabo and Erzha villages where the groundwater is used to irrigate vegetable farmlands, cauliflower, broccoli, lettuce, beet, tomato, Chinese cabbage, green pepper, red pepper, lantern chilli, cucumber were sampled for nitrate concentration. The measurement results are compiled in Figure 5.

The nitrate concentration in broccoli leaf was as high as $5300 \mathrm{mg} / \mathrm{kg}$. However, the nitrate concentrations in broccoli thick stalk and flower head were $2600 \mathrm{mg} / \mathrm{kg}$ and $860 \mathrm{mg} / \mathrm{kg}$, respectively. Cauliflower and Chinese cabbage contained high amount of nitrate in leaf but much less in edible part. Among all measured, lettuce was the only one having very high concentrations in both leaf and root. Beet leaf and root had quite the same but moderate amount of nitrate. It should be noted that both the leaf and root of lettuce are consumed as food by humans. For broccoli, fleshy flower head and the top part of thick stalk are edible. Beet is now usually used for making sugar.

The study by Santamaria [17] showed a decreasing order of the nitrate content in vegetable organs from leaf, stem to root. The present study, however, found that the nitrate in lettuce and beet could have quite uniform distribution. Furthermore, the present study revealed that the nitrate content in seed-corn plant can be listed in the decreasing order from brace roots, stalk to niblets.

The European Commission has established maximum levels (MLs) for nitrate in lettuces [27]. For summer harvest, the limit is $2500 \mathrm{mg} / \mathrm{kg}$ for those grown in the open air and 3500 for those grown under cover. For winter harvest, it is $4000 \mathrm{mg} / \mathrm{kg}$ for those grown in the open air and $4500 \mathrm{mg} / \mathrm{kg}$ for those grown under cover. Judging from European standards, the lettuce produced in Zhangye ought to be viewed as a health risk.

Guojiabo and Erzha villages are about $1.5 \mathrm{~km}$ apart and their drinking water is taken from wells about $30 \mathrm{~m}$ deep. Measurements found that the nitrate concentration in their drinking water was $78 \mathrm{mg} / \mathrm{kg}$ in the Guojiabo village and as high as $160 \mathrm{mg} / \mathrm{kg}$ in the Erzha village. By contrast, the nitrate concentration of the drinking water in

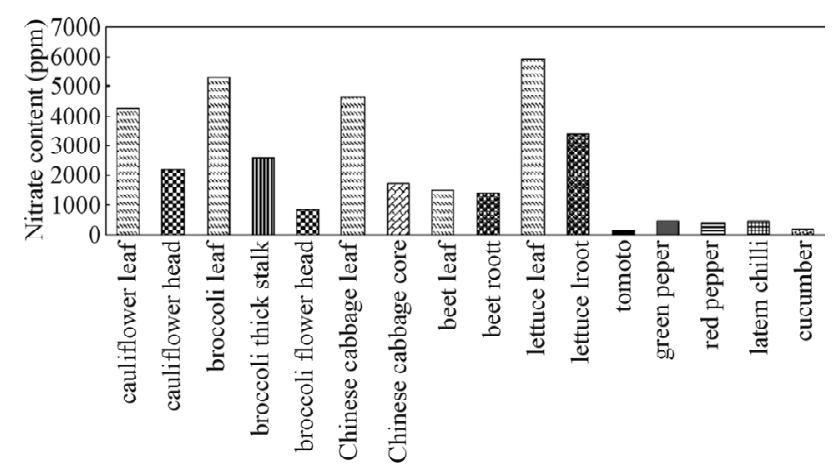

Figure 5. Nitrate contents in various agricultural products. the Yangjiazha village was $34 \mathrm{mg} / \mathrm{kg}$. This suggests that a cycle of groundwater contamination could have formed in vegetable-growing villages as illustrated in Figure 6.

\section{Conclusions}

Although previous studies have reported nitrate contamination of groundwater in the Zhangye Basin, it was not clear if the contaminated groundwater was actually used by local residents for drinking and cooking. By home visiting and testing nitrate concentration of water used for drinking and cooking, this study provided evidence of severe nitrate contamination of drinking water in the Zhangye Basin. Meanwhile, this work improved understanding of nitrate contamination of food by revealing that the edible parts of various crops such as corn niblets, broccoli flower head are much less contaminated compared with non-edible parts such corn stalk and Chinese cabbage leaf. The nitrate in lettuce and beet was found to have quite uniform distribution, but nitrate content in seed-corn plant can be listed in the decreasing order from brace roots, stalk to niblets. Among all measured, lettuce is the only one having very high concentration in edible parts. Therefore, it may be stated that many crops adjust their nitrate content distributions in favor of humans.

The build-up of nitrate in corn plant is affected by the type of irrigation water. The use of sewage water for irrigation due to water scarcity may cause more nitrate build-up in corn stalk. Meanwhile, production of vegetables in the Zhangye Basin mainly uses groundwater. The excessive use of fertilizer has resulted in not just higher contents of nitrate in vegetables but also groundwater contamination, which is the source of drinking water in that region.

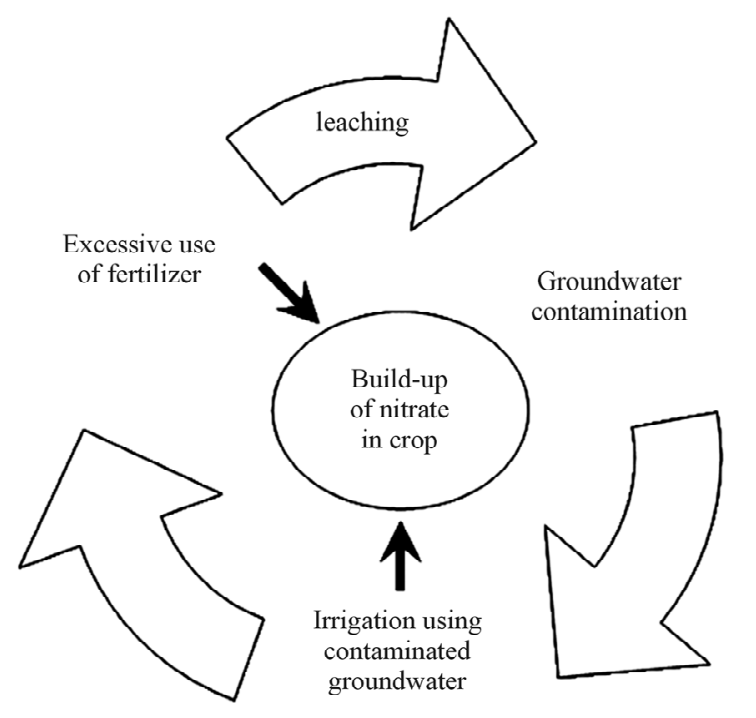

Figure 6. Cycle of nitrate build-up in vegetables and groundwater contamination. 


\section{Acknowledgements}

Thanks should be given to Liu Huan, Li Ling, graduate students of Sophia University, for their assistance in field work. Appreciation also goes to Dr. T. Akiyama, the University of Tokyo, and Dr. Li Jia, the University of Niigata Prefecture, for their support and arrangement prior to and during the field investigation. Above all, the most sincere gratitude and appreciation go to Prof. Li Xin and Prof. Ma Mingguo, Cold and Arid Regions Environment and Engineering Research Institute, Chinese Academy of Sciences. Without their generous support and cooperation, this investigation would become very difficult if not impossible.

\section{REFERENCES}

[1] T. Addiscott, "Nitrate, Agriculture and the Environment," CABI, Wallingford, 2005.

[2] L. Razowska-Jaworek and A. Sadurski, "Nitrate in Groundwaters," IAH Hydrogeology Selected Papers 5, 2004, pp. 247-258.

[3] H. Vroomen, "Fertilizer Use and Price Statistics," Resource and Technology Division, ERS, USDA, Statistics Bulletin, 1989, pp. 780.

[4] P. Heffer, "Assessment of Fertilizer Use by Crop at the Global Level: 2006/07-2007/08," International Fertilizer Industry Association, Paris, 2009.

[5] D. Majumdar, "The Blue Baby Syndrome: Nitrate Poisoning in Humans," Resonance, Vol. 8, No. 10, 2003, pp. 2030. doi:10.1007/BF02840703

[6] M. C. Dutt, H. Y. Lim and R. K. H. Chew, "Nitrate Consumption and the Incidence of Gastric Cancer in Singapore," Food and Chemical Toxicology, Vol. 25, No. 7, 1987, pp. 515-520. doi:10.1016/0278-6915(87)90202-X

[7] E. Moore and E. Matalon, "The Human Costs of NitrateContaminated Drinking Water in the San Joaquin Valley," Report of Pacific Institute, 2011.

[8] R. C. Parslow, G. R. Law, P. A. McKinney, A. Staines, R. Williams and H. J. Bodansky, "Incidence of Childhood Diabetes Mellitus in Yorkshire, Northern England, Is Associated with Nitrate in Drinking Water: An Ecological Study," Diabetologia, Vol. 40, No. 5, 1997, pp. 550-556. doi:10.1007/s001250050714

[9] J. Dich, R. Jarvinen, P. Knekt and P. L. Penttila, "Dietary Intakes of Nitrate, Nitrite and NDMA in the Finnish Mobile Clinic Health Examination Survey," Food Additives and Contaminants, Vol. 13, No. 5, 1996, pp. 541-552. doi:10.1080/02652039609374439

[10] M. Eichholzer and F. Gutzwiller, "Dietary Nitrates, Nitrites, and N-Nitroso Compounds and Cancer Risk: A Review of the Epidemiologic Evidence," Nutrition Reviews, Vol. 56, No. 4, 1998, pp. 95-105. doi:10.1111/i.1753-4887.1998.tb01721.x

[11] S. De Martin and P. Restani, "Determination of Nitrates by a Novel ion Chromatographic Method: Occurrence in Leafy Vegetables (Organic and Conventional) and Expo- sure Assessment for Italian Consumers," Food Additives and Contaminants, Vol. 20, No. 9, 2003, pp. 787-792. doi:10.1080/0265203031000152415

[12] J. Susin, V. Kmecl and A. Gregorcic, "A Survey of Nitrate and Nitrite Content of Fruit and Vegetables Grown in Slovenia during 1996-2002," Food Additives and Contaminants, Vol. 23, No. 4, 2006, pp. 385-390. doi:10.1080/02652030600573715

[13] A. Petersen and S. Stoltze, "Nitrate and Nitrite in Vegetables on the Danish Market: Content and Intake," Food Additives and Contaminants, Vol. 16, No. 7, 1999, pp. 291-299. doi:10.1080/026520399283957

[14] W. Zhong, C. Hu and M. Wang, "Nitrate and Nitrite in Vegetables from North China: Content and Intake," Food Additives and Contaminants, Vol. 19, No. 12, 2002, pp. 1125-1129. doi:10.1080/0265203021000014806

[15] A. Ayaz, A. Topeu and M. Yurttagul, "Survey of Nitrate and Nitrite Levels of Fresh Vegetables in Turkey," Journal of Food Technology, Vol. 5, No. 2, 2007, pp. 177-179.

[16] T. Tamme, M. M. Reinik, M. Roasto, K. Juhkam, T. Tennc and A. Kiis, "Nitrates and Nitrites in Vegetables and Vegetable-Based Products and Their Intakes by the Estonian Population," Food Additives and Contaminants, Vol. 23, No. 4, 2006, pp. 355-361. doi: $10.1080 / 02652030500482363$

[17] P. Santamaria, A. Elia and F. Serio, "Ways of Reducing Rocket Salad Nitrate Content," Acta Horticulture, Vol. 548, 2001, pp. 529-537.

[18] M. Andrews, "The Partitioning of Nitrate Assimilation between Root and shoot of Higher Plants," Plant, Cell \& Environment, Vol. 9, No. 7, 2006, pp. 511-519.

[19] JECFA, "Evaluation of Certain Food Additives and Contaminants," WHO Technical Report Series 859, 1995, pp. 32-35.

[20] SCF Scientific Committee for Food, "Opinion on Nitrates and Nitrites," Reports of the Scientific Committee for Food 38th Series, 1995, pp. 1-33.

[21] Y. Z. Su, Z. H. Zhang and R. Yang, "Amount of Irrigation and Nitrogen Application for Maize Grown on Sandy Farmland in the Marginal Oasis in the Middle of Heihe River Basin," Acta Agronomica Sinica, Vol. 33, No. 1, 2007, pp. 2007-2015. (in Chinese)

[22] R. Yang and W. Liu, "Nitrate Contamination of Groundwater in an Agroecosystem in Zhangye Oasis, Northwest China," Environmental Earth Sciences, Vol. 61, No. 1, 2010, pp. 123-129. doi:10.1007/s12665-009-0327-7

[23] J. Fang and Y. J. Ding, "Assessment of Groundwater Contamination by $\mathrm{NO}_{3}^{-}$Using Geographical Information System in the Zhangye Basin, Northwest China," Environmental Earth Sciences, Vol. 60, No. 4, 2010, pp. 809816. doi:10.1007/s12665-009-0218-y

[24] C. Y. Zhang, Z. Wang and X. X. Cheng, "Studies of Nitrogen Isotopes in Sources of Nitrate Pollution in Groundwater beneath the City of Zhangye," Journal of Arid Land Resources \& Environment, Vol. 18, No. 1, 2004, pp. 7985. (in Chinese)

[25] D. Qin, Y. Qian, L. Han, Z. Wang, C. Li and Z. Zhao, 
"Assessing Impact of Irrigation Water on Groundwater Recharge and Quality in Arid Environment Using CFCs, Tritium and Stable Isotopes, in the Zhangye Basin, Northwest China," Journal of Hydrology, Vol. 405, No. 1-2, 2011, pp. 194-208. doi:10.1016/j.jhydrol.2011.05.023

[26] B. E. Gilbert, "The Adaptation of Certain Colorimetric Methods to the Estimation of Nitrates, Phosphates and Po- tassium in Plant Solutions," Plant Physiology, Vol. 2, No. 2, 1926, pp. 191-199. doi:10.1104/pp.1.2.191

[27] European Commission, "Commission Regulation (EC) No.1881/2006 of 19 December 2006 Setting Maximum Levels for Certain Contaminants in Food Stuffs," 2006. 